\title{
Essential Minerals of Rice in West Java Indonesia and its Daily Intake Estimation
}

\author{
W.Y.N Syahfitri, E. Damastuti, N. Adventini, D.P.D. Atmodjo, I. Kusmartini, \\ S. Kurniawati, D.D. Lestiani and M. Santoso \\ Center for Applied Nuclear Science and Technology, National Nuclear Energy Agency \\ Jl. Tamansari No.71, Bandung 40132, Indonesia
}

\section{ARTICLE INFO}

Article history:

Received 16 November 2016

Received in revised form 10 October 2018

Accepted 11 October 2018

Keywords:

Rice

Essential mineral

Daily intake

Neutron activation analysis

\begin{abstract}
A B S T R A C T
Rice (Oryza sativa L.) is the staple food for more than half of the world's population and a major source of essential minerals. Essential minerals such as cobalt (Co), chromium $(\mathrm{Cr})$, iron $(\mathrm{Fe})$, selenium $(\mathrm{Se})$, and zinc $(\mathrm{Zn})$ play an important role in metabolism and physiological function. Information of rice micronutrient and its content quality in Indonesia is limited; however, its availability is important for estimating the daily intake of the nutrients and its contribution to the Recommended Dietary Allowance (RDA). The research aimed to determine the micronutrient content in rice from twelve regions in West Java by means of neutron activation analysis (NAA) and estimate the nutrient intake from rice. The samples were irradiated with thermal neutron flux of $10^{13} \mathrm{n} /\left(\mathrm{cm}^{2} \mathrm{~s}\right)$ at the rabbit system facilites of the G.A. Siwabessy multipurpose reactor, then counted using a HPGe detector. The contents of $\mathrm{Co}, \mathrm{Cr}, \mathrm{Fe}, \mathrm{Se}$, and $\mathrm{Zn}$ in rice were found to be in the ranges of 0.003 to $0.220, \leq 0.001-0.679, \leq 0.060-18.36, \leq 0.020-0.975$, and $8.558-28.83 \mathrm{mg} / \mathrm{kg}$ respectively. The daily intakes of $\mathrm{Co}$ and $\mathrm{Cr}$ were found generally sufficient, while $\mathrm{Fe}, \mathrm{Se}$, and $\mathrm{Zn}$ intakes were significantly less than the RDA in almost all regions observed. The exception was found for Se intake in Garut which exceeded its RDA. It can be concluded that rice is the main contributor of essential minerals intake; however, for nutritional fulfillment of human body, a balanced varied diet should be taken into consideration.
\end{abstract}

(C) 2018 Atom Indonesia. All rights reserved

\section{INTRODUCTION}

Essential mineral elements have many functions and play an important role in biochemical processes due to their direct or indirect effects on human metabolism [1,2]. Several examples of essential minerals are: cobalt (Co), chromium (Cr), iron $(\mathrm{Fe})$, selenium $(\mathrm{Se})$, and zinc $(\mathrm{Zn})$. Cobalt, as a part of vitamin $B_{12}$, stimulates the production of red bloods cells and it is related to the activities of brain and nervous system [2,3]. Chromium is needed to help maintaining normal blood glucose levels/insulin activity [3]. Iron is a component of hemoglobin and numerous enzymes, where it prevents microcytic hypochromic anemia [3,4]. Selenium is involved in important biological activities, especially related to hormones metabolism and the immune system [2] due to its

\footnotetext{
* Corresponding author

E-mail address: woro@batan.go.id

DOI: https://doi.org/10.17146/aij.2018.922
}

antioxidant and anticancer properties [5]. Zinc is connected to the metalloproteinases, which are involved in processes of gene regulation [2,3].

Information on micronutrient contents of rice listed in Food Composition Tables in Indonesia is still very limited, obsolete, and generally based on a compilation of nutrient data from other countries [6]; thus, the data can not representatively describe the nutrient composition in Indonesian rice and the nutrient status of people in a particular population. Therefore, the availability of latest information about the composition of the essential mineral content in rice is indispensable.

Multi-element analysis methods in rice are necessary due to the increasing needs for more detailed information of nutrient composition in food and nutrient status of a person in a population. For these purposes a wide range of instrumental analytical techniques have been used. Several methods, such as flame atomic absorption spectrometry (FAAS) and inductively coupled 
plasma mass spectrometry (ICPMS), are fairly popular and frequently used for elemental determination in rice samples by several countries [7-9]. However, these techniques imply a prior total destruction, which may lead to the contamination problems from the reactants employed. Moreover, the samples' destruction strongly depends on the chemical composition of the sample and on the element to be determined. The standard used in Atomic Absorption Spectroscopy (AAS) is made of a compound of each element, making it less effective in terms of preparation time and poses high risk due to the contaminant chemical compounds. Given the nutritional benefits and health issues associated with $\mathrm{Se}$ supplementation and other essential mineral, it is very important to ensure that rapid and sensitive analytical methods for simultaneous determination of multi-elements including $\mathrm{Se}$ in rice are available. Instrumental neutron activation analysis (INAA) is known as a powerful technique for the determination of various elements in food samples. It is also a nondestructive, sensitive, selective, simultaneous multi-element analytical technique with a very low detection limits that can be used for the investigation of rice samples [10].

Some countries are already using NAA method for the determination of minerals in rice. Moon et al. undertook collaborative studies for the analysis of white rice in seven Asian countries and obtained the contents of some elements, including As, $\mathrm{K}, \mathrm{Mn}, \mathrm{Na}, \mathrm{Co}, \mathrm{Cr}, \mathrm{Fe}$, and $\mathrm{Zn}$, and daily intake for As, K, Mn, Na, and Zn [11]. Research activities related to the characterization of minerals in rice in Indonesia had been conducted by M. Wiyono et al. which focus on several areas in Java Island, with the results of the mineral content in rice being in accordance with seven other Asian countries [12]. It implies that rice provides important information of mineral supplement as well as a large portion of calories for Asians. As scientists have focused their research on health impacts caused by mineral nutrient deficiency and hazardous elements, public concerns about mineral intake by dietary food is rising worldwide [11].

West Java was chosen for this research because the population of this province is the largest in Indonesia [13], and it is one of the main production center of rice with a contribution of $17.6 \%$ of the national rice production, which is able to meet the needs of rice for 42.2 million people and provides a surplus of more than one million tons for the population outside of the province [14].

The aims of this research were to determine the essential minerals in the rice and to estimate the nutrient intake of local inhabitants by observing the rice that is main staple food in their diet. For that reason, the rice samples were taken based on the most frequently consumed rice varieties in several area of West Java. The rice samples were bought in traditional markets based on mostly consumed in twelve regions of West Java. This research activity also included daily intake estimation of $\mathrm{Co}, \mathrm{Cr}, \mathrm{Fe}$, $\mathrm{Se}$, and $\mathrm{Zn}$ related to the nutritional status of people in West Java.

\section{EXPERIMENTAL METHODS}

\section{Materials}

The Rice Flour Standard Reference Material (SRM 1568a) was obtained from the National Institute of Standards and Technology. Demineralized water $(>18 \mathrm{M} \Omega \mathrm{cm})$ was used throughout this work. Other materials used were the multi-elements standard solutions (ICP E. Merck), titrisol standard solution (E. Merck), polyethylene vials, and samples of various varieties of rice such as Setra, Kurmo, Jembar, and Pandan Wangi.

\section{Sample collection}

White rice samples were collected from traditional markets in Bogor (Kurmo and Jembar varieties), Sukabumi (Setra and Jembar), Bandung (Kurmo and Jembar), Cirebon (Setra), Bekasi (Setra), Tasikmalaya (Setra and Pandan Wangi), Indramayu (Setra), Lembang (Setra), Majalaya (Setra), Garut (Setra, Jembar, and Kurmo), Cianjur (Setra and Jembar), and Karawang (Setra), West Java. Setra is the trade name of the IR-64 rice variety while Jembar, Kurmo, and Pandan Wangi are local rice variety in West Java. Figure 1 shows the sampling locations.

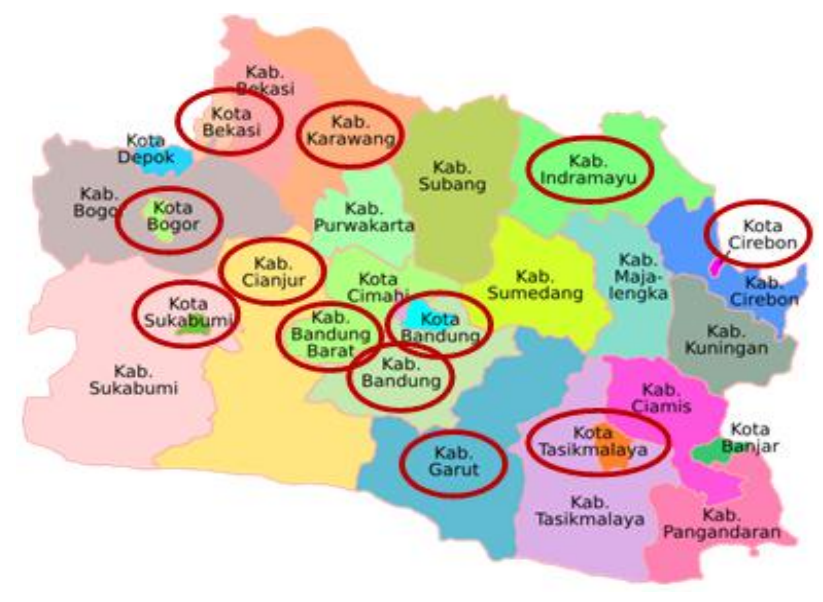

Fig. 1. Sampling locations in twelve regions in West Java province (reprinted from https://lahanindustri.files. wordpress.com/2016/10/jawa-barat-maps.png). 


\section{Standard and sample preparation}

A standard solution was prepared for 1, 1.01, $10,10.2$ and $10 \mu \mathrm{g}$ of $\mathrm{Co}, \mathrm{Cr}, \mathrm{Fe}, \mathrm{Se}$, and $\mathrm{Zn}$, respectively, from the standard solution of ICP multi-element standard solution VI from E. Merck, and an additional $49.9 \mu \mathrm{g}$ of $\mathrm{Fe}$ from the standard solution of $1000 \mathrm{mg} \mathrm{Fe}\left(\mathrm{FeCl}_{3}\right.$ in $\left.15 \% \mathrm{HCl}\right)$ titrisol from E. Merck.

A representative portion from each white rice sample was crushed to a homogeneous fine powder by using titanium-blade blender. About $40 \mathrm{mg}$ of sample and NIST 1568a were each weighed and put into $0.3 \mathrm{~mL}$ polyethylene vials and then sealed by heat. The samples were then irradiated for two hours at $15 \mathrm{MW}$ and thermal neutron flux of $10^{13}$ $\mathrm{n} /\left(\mathrm{cm}^{2} \mathrm{~s}\right)$, along with the Standard Reference Material (SRM) 1568a and the aforementioned standard solution, in the rabbit system facilites of multipurpose reactor G.A. Siwabessy [3,15]. The properties of the radionuclides used, $\gamma$-ray energies, and other details of the analysis are presented in Table 1.

Table 1. Nuclear parameters of all essential elements $[6,16]$.

\begin{tabular}{ccccc}
\hline Element & Radionuclide & Half-life & $\begin{array}{c}\gamma \text {-ray } \\
(\mathrm{keV})\end{array}$ & $\begin{array}{c}\text { Irradiation } \\
\text { time }(\mathrm{h})\end{array}$ \\
\hline Co & Co-60 & $5.271 \mathrm{y}$ & 1332.50 & 2 \\
$\mathrm{Cr}$ & $\mathrm{Cr}-51$ & $27.704 \mathrm{~d}$ & 320.08 & 2 \\
$\mathrm{Fe}$ & $\mathrm{Fe}-59$ & $44.496 \mathrm{~d}$ & 1099.25 & 2 \\
$\mathrm{Se}$ & $\mathrm{Se}-75$ & $119.77 \mathrm{~d}$ & 264.66 & 2 \\
$\mathrm{Zn}$ & $\mathrm{Zn}-65$ & $243.8 \mathrm{~d}$ & 1115.52 & 2 \\
\hline
\end{tabular}

\section{Measurement of essential mineral}

After the appropriate decay times, all elements were analyzed using a gamma spectrometer (Canberra, United States) equipped with a high-purity germanium (HPGe) detector with relative efficiencies of $15 \%$ and $35 \%$ and a resolution of $1.9 \mathrm{keV}$ for the $1332.5 \mathrm{keV}$ peak of Co-60. The $\gamma$-ray spectra were processed using the Genie 2000 software. The $\gamma$-ray activities of samples were counted for 6 to 13 hours for all elements.

\section{Quality control of results}

Quality control was provided by using international standard reference materials (SRM NIST 1568a). The samples and the standard reference materials were treated in the same manner in all analytical steps. The results of SRM analysis were compared with its certificate value and evaluated for its accuracy and precission by percent accuracy and percent RSD (\%RSD) calculation.

\section{Estimated daily intake of elements}

The daily intake of each element is a function of the concentration of the element in the food sample as well as the amount of the food that consumed daily. The estimated daily intake (EDI) of each element was therefore calculated using the following equation: $[2,8,17]$

$$
\mathrm{EDI}=\mathrm{C} \times \mathrm{M}
$$

$\mathrm{C}$ is the mean concentration of element in rice samples $(\mathrm{mg} / \mathrm{kg})$ and $\mathrm{M}$ was the assumed consumption rate $(\mathrm{kg} / \mathrm{d})$ of the people [17]. In this research, the per-person consumption rate was $0.290 \mathrm{~kg} / \mathrm{d}$ for West Java [14]. The obtained values were then compared with the Recommended Dietary Allowance (RDA). The RDA is the average daily intake level that is sufficient to meet the nutrient requirements of nearly all (97-98\%) healthy individuals in a particular life stage and gender group and it is commonly used as a standard value in assessing the adequacy of daily intake [3]. The RDA value for adult man and women are described in Table 2 as follow.

Table 2. Recommended Dietary Allowance for adult men and women $>19$ years old.

\begin{tabular}{cccc}
\hline \multirow{2}{*}{ No } & Element & \multicolumn{2}{c}{$\mathrm{RDA}(\mathrm{mg} / \mathrm{d})$} \\
& & men & women \\
\hline 1 & Co [18] & $0.005^{*}$ & $0.045^{*}$ \\
2 & Cr [19] & 0.035 & 0.025 \\
3 & Fe [19] & 8 & 18 \\
4 & Se [5] & 0.055 & 0.055 \\
5 & Zn [19] & 11 & 8 \\
\hline
\end{tabular}

*The range biological control on Co

\section{Contribution of essential mineral}

The estimated contribution of the various rice to the daily intake of each elements was therefore calculated using the following equation:

$$
\text { Contribution }=\frac{\mathrm{EDI}}{\mathrm{RDA}} \times 100 \%
$$

\section{RESULTS AND DISCUSSION}

\section{Quality control}

The result of the quality control assesment with SRM NIST 1568a Rice Flour is listed in 
Table 3. Table 3. showed that the results obtained are in good agreement with the certified values.

Table 3. Quality control assessment using NIST Rice Flour 1568a SRM.

\begin{tabular}{ccccccc}
\hline & \multicolumn{3}{c}{ SRM NIST RF 1568a Rice Flour } & \multicolumn{3}{c}{ Acceptable [20] } \\
Elements & $\begin{array}{c}\text { Certified } \\
\text { Value } \\
(\mathrm{mg} / \mathrm{kg})\end{array}$ & Result & \multicolumn{3}{c}{ Accuracy Precision } & $\begin{array}{c}\text { Accuracy Precision } \\
\text { range }\end{array}$ \\
& $(\mathrm{mg} / \mathrm{kg})$ & $\%$ & $\%$ RSD & $\%$ & $\%$ RSD \\
\hline $\mathrm{Co}$ & 0.018 & $0.0184 \pm 0.001$ & 102 & 4.6 & $60-115$ & 21 \\
$\mathrm{Fe}$ & $7.40 \pm 0.9$ & $7.35 \pm 0.6$ & 99 & 0.1 & $80-110$ & 7.3 \\
$\mathrm{Se}$ & $0.38 \pm 0.04$ & $0.36 \pm 0.03$ & 95 & 8.6 & $80-110$ & 11 \\
$\mathrm{Zn}$ & $19.4 \pm 0.5$ & $20.3 \pm 1.3$ & 105 & 6.6 & $80-110$ & 7.3 \\
\hline
\end{tabular}

The resulting accuracy range was $95-105 \%$ and precision $0.1-8.6 \%$, while for $\mathrm{Cr}$, since this element is not included in the certified quality assesment, its quality control were applied using traceable and certified ICP multi-element standard solution VI Certipur. Its accuracy and precission were found to be $96 \%$ and $9.7 \%$, respectively.

\section{Concentration of essential minerals in rice samples}

The concentration of essential minerals in white rice samples from West Java Indonesia are listed in Table 4.

Table 4. Range values of essential mineral concentrations determined in white rice from West Java Indonesia.

\begin{tabular}{|c|c|c|c|c|c|}
\hline \multirow{2}{*}{$\begin{array}{c}\text { Sampling } \\
\text { Location }\end{array}$} & \multicolumn{5}{|c|}{ Essential mineral content (mg kg-1 wet weight) } \\
\hline & Co & $\mathrm{Cr}$ & $\mathrm{Fe}$ & $\mathrm{Se}$ & $\mathrm{Zn}$ \\
\hline \multicolumn{6}{|c|}{ This Study } \\
\hline Bogor & $0.003-0.004$ & $\leq 0.001-0.12$ & $\leq 0.060-4.12$ & $\leq 0.020$ & $12.43-13.57$ \\
\hline Sukabumi & $0.034-0.065$ & $0.104-0.137$ & $4.56-12.49$ & $\leq 0.020-0.115$ & $9.037-18.57$ \\
\hline Bandung & $0.013-0.040$ & $0.115-0.143$ & $3.55-11.4$ & $\leq 0.020$ & $9.83-14.12$ \\
\hline Cirebon & $0.044-0.093$ & $\leq 0.001-0.134$ & $10.29-10.32$ & $\leq 0.020$ & $8.558-19.16$ \\
\hline Bekasi & $0.049-0.139$ & $0.092-0.222$ & $12.72-18.15$ & $\leq 0.020-0.088$ & $10.62-28.83$ \\
\hline Tasikmalaya & $0.049-0.070$ & $0.234-0.448$ & $\leq 0.060$ & $\leq 0.020-0.178$ & $10.08-18.44$ \\
\hline Indramayu & $0.045-0.074$ & $0.093-0.120$ & $7.465-18.36$ & $0.055-0.086$ & $15.80-18.36$ \\
\hline Lembang & $0.054 \pm 0.003$ & $0.082 \pm 0.004$ & $6.623 \pm 1.21$ & $0.156 \pm 0.023$ & $12.64 \pm 0.153$ \\
\hline Majalaya & $0.032 \pm 0.003$ & $0.057 \pm 0.007$ & $5.567 \pm 0.77$ & $0.107 \pm 0.011$ & $8.674 \pm 0.011$ \\
\hline Garut & $0.077-0.11$ & $0.086-0.149$ & $11.91-15.64$ & $0.048-0.975$ & $12.48-15.64$ \\
\hline Cianjur & $0.048-0.220$ & $0.102-0.138$ & $7.073-13.10$ & $0.129-0.206$ & $12.05-12.64$ \\
\hline Karawang & $0.005 \pm 0.0002$ & $0.679 \pm 0.035$ & $17.7 \pm 2.43$ & $\leq 0.020$ & $22.96 \pm 0.303$ \\
\hline \multicolumn{6}{|c|}{ Other Studies } \\
\hline Bandung [3] & $0.012-0.254$ & $0.004-0.180$ & $0.080-9.180$ & $0.060-0.290$ & $11.9-160$ \\
\hline Saudi Arabia [7] & $0.001-0.116$ & $0.010-0.184$ & $1.950-55.10$ & $0.007-0.574$ & $1.150-13.50$ \\
\hline $\begin{array}{l}\text { Australia } \\
\text { (Brisbane) [7] }\end{array}$ & $0.013-0.026$ & $0.033-0.390$ & $1.750-6.470$ & $0.002-0.150$ & $8.440-18.30$ \\
\hline Spain [8] & $0.120 \pm 0.090$ & $0.110 \pm 0.050$ & $6.800 \pm 1.500$ & $0.200 \pm 0.190$ & $13.50 \pm 3.400$ \\
\hline Brazil [9] & $0.011-0.058$ & $2.700-3.300$ & $0.600-6.600$ & $0.048-0.090$ & $15.70-26.40$ \\
\hline Jamaica [19] & $0.097 \pm 0.018$ & $0.080 \pm 0.036$ & $22.30 \pm 37.90$ & $0.108 \pm 1.900$ & $15.60 \pm 1.900$ \\
\hline $\begin{array}{l}\text { Indonesia } \\
\text { (Jakarta) [11] }\end{array}$ & 0.770 & 0.380 & 4.650 & - & 24.20 \\
\hline
\end{tabular}




\section{Essential elements}

The elemental concentrations of rice sample taken from twelve regions measured by INAA were presented in Table 4. The concentrations of $\mathrm{Co}, \mathrm{Cr}$, $\mathrm{Fe}, \mathrm{Se}$, and $\mathrm{Zn}$ were observed as the essential element for all studied samples. The order of the mean concentrations of element was $\mathrm{Zn}>\mathrm{Fe}>\mathrm{Se}>$ $\mathrm{Cr}>\mathrm{Co}$ with the concentrations in the ranges of 8.558-28.83, $\leq 0.06-18.36, \leq 0.020-0.975, \leq 0.001$ 0.679 , and $0.003-0.220 \mathrm{mg} / \mathrm{kg}$, respectively. Elemental concentrations in rice from Bandung in this study was found slightly different from previous research by Damastuti et al. [3] due to differences in rice variety.

Table 4 shows the variation within the element concentration obtained from the twelve regions in West Java. Those variations are attributed to many factors such as the mineral composition of the soil, soil type, fertilizers, agricultural chemicals [21], cultivar of plant, weather conditions during the growth, and the state of plant maturity at harvest [22]. Furthermore, those variations are also affected by soil $\mathrm{pH}$, cation exchange capacity, soil texture, and the interaction of soil plant root microbes which play important roles in regulating movement from soil to the edible parts of plant. Additionally, different metal species in different forms have differing abilities to migrate from the soil through the plant parts and avail itself for consumption. This ability, represented by the transfer factor [23], also influences the concentration of the metal's concentration in rice.

The content of $\mathrm{Co}, \mathrm{Cr}, \mathrm{Fe}, \mathrm{Se}$, and $\mathrm{Zn}$ in rice generally corresponded with previously reported data from other countries [7-9,11,19].

\section{Cobalt (Co)}

The cobalt concentration in white rice ranged from 0.003 to $0.220 \mathrm{mg} / \mathrm{kg}$ whereas the mean concentration was found to be $0.056 \mathrm{mg} / \mathrm{kg}$. The mean concentration of Co from the twelve regions in West Java were similar with those from Saudi Arabia, Spain, and Brazil, but higher than the 0.01 $\mathrm{mg} / \mathrm{kg}$ wet base as found in Brisbane, Australia, and Finland [22]. Cobalt is an essential trace nutrient. As it is present in small amounts in most foods, deficiency of it is rarely found. However, lack of Co may lead to pernicious anemia which can be fatal [19].

\section{Chromium (Cr)}

The chromium content in the white rice samples ranged from $\leq 0.001$ to $0.679 \mathrm{mg} / \mathrm{kg}$ and the mean chromium content of the samples was 0.179 $\mathrm{mg} / \mathrm{kg}$. The highest value, $0.679 \mathrm{mg} / \mathrm{kg}$, was found in Karawang rice. It can be caused by the very intensive and continuous use of phosphate fertilizers, and is thought to cause the accumulation of metals contained in the fertilizer in the soil, some of which will be absorbed by plants and partly leached into the soil.

Humans require chromium in trace amounts. Its mechanisms in the body are not well defined but it is known to enhance the action of insulin, and appears to aid in the metabolism and storage of protein, carbohydrates, and fats. Chromium is present in very low levels in food and its absorption rates in the body are low, between $0.4 \%$ and $2.5 \%$. It is primarily found in two forms, $\mathrm{Cr}(\mathrm{III})$, which is biologically active, and $\mathrm{Cr}(\mathrm{VI})$, which is a pollutant and potentially toxic $[7,19]$.

\section{Iron (Fe)}

The iron content of white rice ranged from $\leq 0.06$ to $18.36 \mathrm{mg} / \mathrm{kg}$ and the mean value found in white rice was $9.712 \mathrm{mg} / \mathrm{kg}$. The rice samples from Tasikmalaya had iron levels below the limit of detection, therefore the rice that was most consumed by the inhabitants of Tasikmalaya had the lowest detected concentration of $\mathrm{Fe}$, while the highest value was found in Karawang rice samples. However, the iron content in Karawang was still below those in Saudi Arabia and Jamaica. The mean iron content of rice sample in West Java is similar with national food database's value of $7.3 \pm 2.5 \mathrm{mg} / \mathrm{kg}$ [8].

The amount of bioavailable iron in rice and other staple plants is low, and the phytic acid present in rice may add to this lack of bioavailability. This is a likely contributor to the global iron deficiency problem [19]. Iron biofortification is difficult as many beneficial $\mathrm{Fe}$ compounds $\left(\mathrm{FeSO}_{4}\right)$ are unpalatable, and less soluble $\mathrm{Fe}$ compounds are poorly absorbed. Increasing the $\mathrm{Fe}$ content of rice is a difficult task for several reasons. Although $\mathrm{Fe}$ is abundant in the soil, plants cannot utilize it as it is mainly present as the largely insoluble Fe(III) compounds.

The fact that calcareous soils with a high $\mathrm{pH}$ account for $30 \%$ of the world's cultivated soils makes the situation worse. On the other hand, Fe is a transition metal that readily accepts and donates electrons. This property of $\mathrm{Fe}$ makes it essential for plants while, at the same time, making it toxic through the production of reactive oxygen species. Thus, plants have developed sophisticated mechanisms to absorb $\mathrm{Fe}$ from soil and transport it from root to shoot and grain [24]. 


\section{Selenium (Se)}

The Se concentrations in rice samples from West Java ranged from $\leq 0.020$ to $0.975 \mathrm{mg} / \mathrm{kg}$ (Table 4). As a comparison, the Se content of rice in Brazil averaged $0.125 \mathrm{mg} / \mathrm{kg}$ with the range of 0.048 to $0.090 \mathrm{mg} / \mathrm{kg}$. The overall average for West Java was higher than the value from Brazil, despite $33 \%$ of the samples having concentrations below detection limit, namely the samples from Bogor, Bandung, Cirebon and Karawang; only $67 \%$ of samples exceeded the detectable level of Se. The highest value was found in Garut rice samples; it was similar with the average of Se concentrations in rice samples collected from Northern Iran, which ranged from $0.50 \mathrm{ppm}$ (Langaroud) to $1.49 \mathrm{ppm}$ (Gonbadkavos) [25].

This variation in Se levels may occur due to the availability in soil. In addition, the concentration of Se can be different not only between samples collected from the different countries in world, but even between samples from different regions of a specific country [2]. Although soil Se concentrations of the geographic origin of the crop is the main determinant of the Se content of foods, other factors such as climatic conditions and the use of Se-rich fertilizers can affect Se concentrations of foodstuffs [25].

\section{Zinc (Zn)}

The average concentration of $\mathrm{Zn}$ in rice from West Java was $14.994 \mathrm{mg} / \mathrm{kg}$ with a range of 8.558$28.83 \mathrm{mg} / \mathrm{kg}$. The lowest value was found in Cirebon rice. The content of zinc in rice sample from Cirebon was similar with the values from Brisbane, Australia, which was in the 8.440-18.30 $\mathrm{mg} / \mathrm{kg}$ range [7]. It is likely that the relatively low zinc concentrations in rice are a function of zincdeficient soils or soils with properties that make this element biologically unavailable for uptake by the plant. It is known that rice and other cereals contain phytic acid, a chelating agent of several trace elements including zinc. The low $\mathrm{Zn}$ concentrations found in the rice and further reduction in the bioavailability of zinc caused by phytates require special attention because of the high prevalence of zinc deficiency in the developing countries [19]. The soil factor most affecting the availability of $\mathrm{Zn}$ is $\mathrm{pH}$. In a study at Bhopal, India, desorption of adsorbed $\mathrm{Zn}$ decreased with increasing $\mathrm{pH}$ and stopped abruptly at $\mathrm{pH} 7.5$. Alternating flooding and drying as occurring under irrigated rice culture also results in increased desorption of $\mathrm{Zn}$ [26]. The WHO lists zinc deficiency as the fifth leading cause of illness and disease in low-income countries, with some estimates suggesting that up to a third of the world's population is affected [19].

\section{Estimation of essential mineral daily intake}

Dietary intake levels of essential minerals for West Javanese people were estimated. Previous research by M. Wiyono et al. [12] focuses on determination of elements in rice in Pandeglang, Indramayu, Tasikmalaya, and Cirebon. However, they did not calculate the daily mineral intake from rice. Therefore, this study provides the daily intake of minerals and uses a larger number of sampling areas. The estimated values and their comparison with the RDA are shown in Figs. 2-6. In estimating the daily intake of inorganic constituents via white rice, a daily consumption survey of white rice is indispensible. Hence, by assuming that the average per-capita consumption of rice is $0.290 \mathrm{~kg} / \mathrm{day}$, daily intake values can be calculated for the five elements of $\mathrm{Co}, \mathrm{Cr}, \mathrm{Fe}, \mathrm{Se}$, and $\mathrm{Zn}$ for all regions and they can be compared with each other. The EDI considers the average rice consumption per capita in West Java and estimates that average value for adults aged 19-50 years. Overall, rice can be an important dietary source of $\mathrm{Co}, \mathrm{Cr}, \mathrm{Fe}, \mathrm{Se}$, and $\mathrm{Zn}$, as it can provide more than $5 \%$ of the RDA. However, its contribution of the elements is highly dependent on the type of rice.

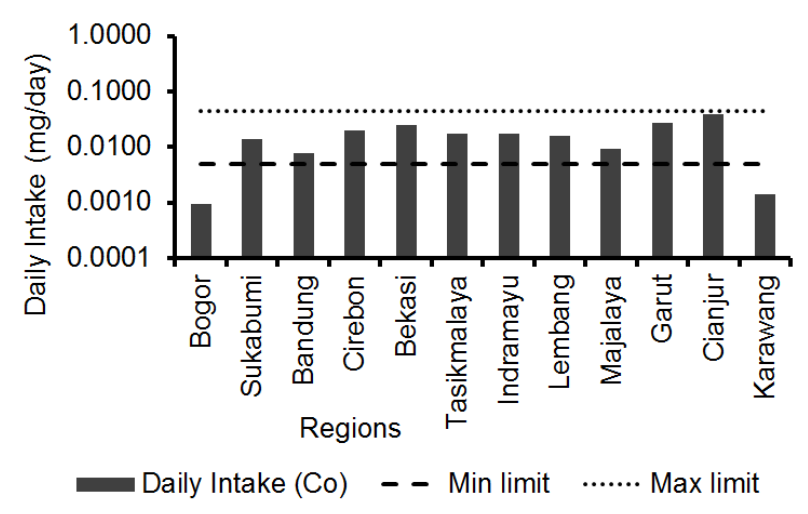

Fig. 2. Estimated daily Co intake.

The cobalt intake from rice exceeded its minimal value $(5 \mu \mathrm{g} /$ day $)$ for biological control on metal in ten regions, as shown in Fig. 2, but its values in all regions were below maximal value (45 $\mu \mathrm{g} /$ day) for biological control and there is no data on RDA and tolerable upper intake level (UL) of cobalt. The UL is the highest level of daily nutrient intake that do not pose a risk of adverse health effects to almost all individuals in the general population [3]. The intake was still within the normal range and safe limit for Co which is from 0.005 to $1.8 \mathrm{mg} / \mathrm{day}$ [27]. The contributions of rice 
from Bogor and Karawang to the daily intake of cobalt were $24 \%$ and $35 \%$ of the RDA values, respectively.

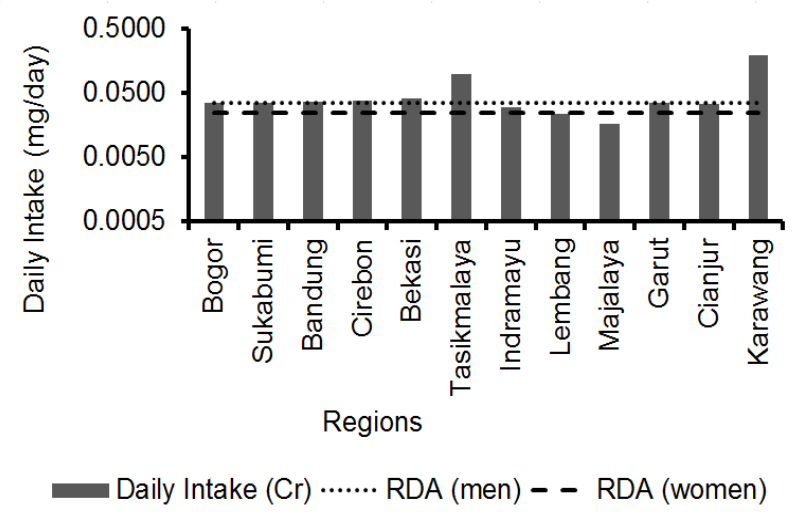

Fig. 3. Estimated daily $\mathrm{Cr}$ intake.

Figure 3 shows the resulting estimates of daily chromium intake. The average daily chromium intake in our study was $0.052 \mathrm{mg} /$ day, which was between those RDA for men dan women aged $>19$ years (Fig. 3, Table 2), with the average daily intake contribution for men and women being 1.5 and 2.1 times of RDA values, respectively. The average $\mathrm{Cr}$ daily intake obtained were also in the range of $0.05-0.2 \mathrm{mg} /$ day as recommended by National Academy of Sciences [18].

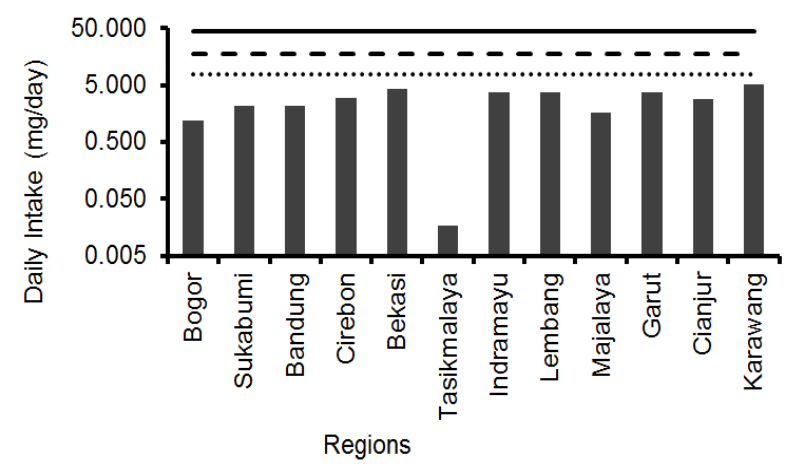

Daily Intake (Fe) …... RDA (men) - - RDA (women) —UL

Fig. 4. Estimated daily Fe intake.

Figure 4 shows that the daily intake of $\mathrm{Fe}$ in twelve regions were below RDA values and the average daily $\mathrm{Fe}$ intake contributes around 0.1-64\% of RDA values for women and men aged $>19$ years, as calculated from the equation (2). According to R. Kukuh, the normal daily input of Fe is $6-40 \mathrm{mg}$ /day [27]. FAO (Food and Agriculture Organization) and WHO (World Health Organization) recommend that the amount of iron that must be consumed should be based on the amount of iron loss from the body. Therefore, the RDA for Fe for men and women, according to their needs, are different [3].

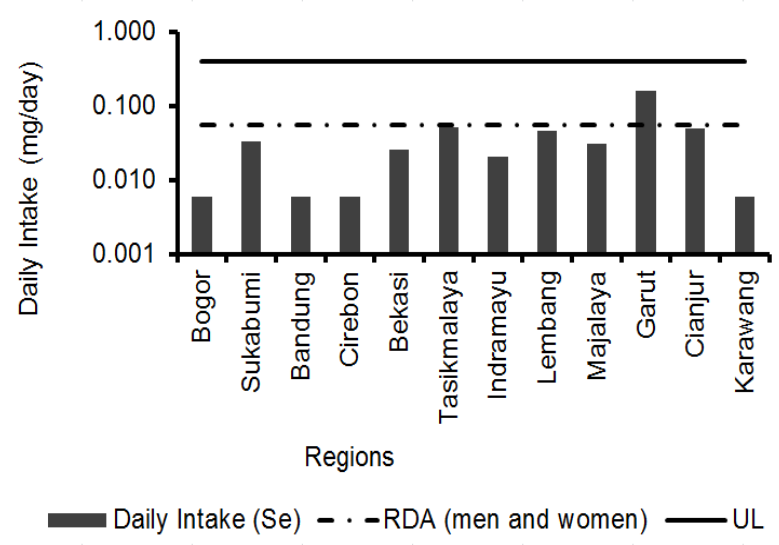

Fig. 5. Estimated daily Se intake.

The daily Se intake from white rice ranged from 0.006 to $0.158 \mathrm{mg} /$ day whereas the mean daily intake was found to be $0.040 \mathrm{mg} /$ day which contributes $73 \%$ of the RDA. Figure 5 shows that the Se daily intake of rice in Garut exceeded the RDA but still below UL ( $400 \mu \mathrm{g} /$ day). Due to the essentiality of $\mathrm{Se}$ and its reported beneficial effects, nutritionists increasingly recommend raising Se intake, especially in regions where environmental Se levels are low [5]. Selenium performs important biological activities, especially related to hormones metabolism and the immune system. Selenium can reduces toxic effects of As and Cd. Studies indicate that an adult's biological needs for Se may be satisfied if at least $70 \mu \mathrm{g} /$ day is provided [2].

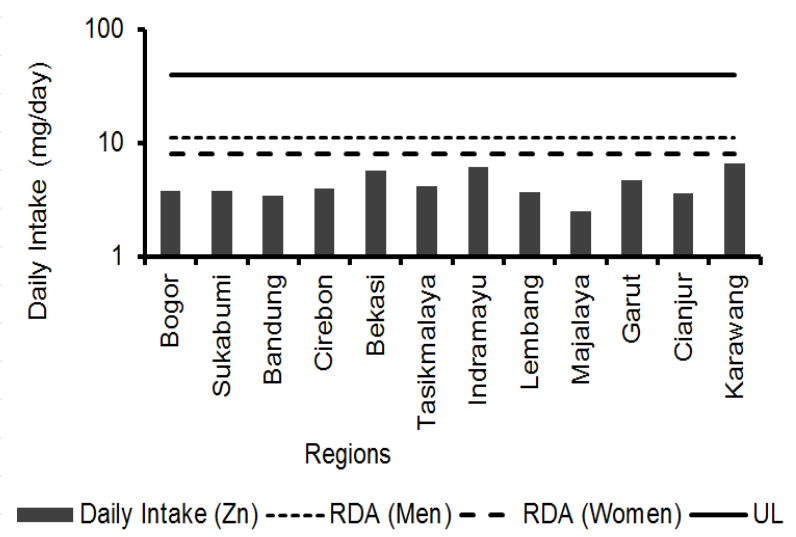

Fig. 6. Estimated daily $\mathrm{Zn}$ intake.

Similarly to the previous elements, the average $\mathrm{Zn}$ intakes were below RDA values, as can be seen in Fig. 6, and contributed $23 \%$ to $83 \%$ of the RDA value. A daily intake of 5 to $40 \mathrm{mg}$ /day is recomended. A high deficiency of $\mathrm{Zn}$ leads to a slow development or congenital malformation $[18,28]$. Therefore, efforts to improve the content of $\mathrm{Zn}$ in rice products are needed to improve nutrition and public health [28]. 


\section{CONCLUSION}

High concentrations of $\mathrm{Zn}$ and $\mathrm{Fe}$ and minor contents of $\mathrm{Se}, \mathrm{Cr}$, and $\mathrm{Co}$ were observed for all white rice samples collected. The contents of Co, $\mathrm{Cr}, \mathrm{Fe}, \mathrm{Se}$, and $\mathrm{Zn}$ in rice generally corresponded with previously reported data in other countries. The daily intakes of $\mathrm{Co}$ and $\mathrm{Cr}$ elements are conveniently supplied by the diet. However, for Fe, $\mathrm{Se}$, and $\mathrm{Zn}$, in almost all regions observed, rice consumption contributed only a low fraction of RDA value, except for the Se content in Garut which exceeded its RDA value. However, rice is the main contributor of essential minerals intake, it is needed to be considered that a healthy diet is not just to fulfill the nutrition requirements but also should consist of a balanced varied diet. Analyses of elements have provided meaningful information on the nutrient database of rice.

\section{ACKNOWLEDGMENT}

The authors would like to extend their thanks to the staff members of Center of Multipurpose Reactor and Center for Applied Nuclear Science and Technology, National Nuclear Energy Agency, Indonesia, who have provided support in the implementation of these research.

\section{REFERENCE}

1. Y. Huang, C. Tong, F. Xu et al., Food Chem. 192 (2016) 873. http://dx.doi.org/10.1016/ J.foodchem.2015.07.087

2 T. Pedron, F.R. Segura, F.F. da Silva et al., J. Food Compos. Anal. 49 (2016) 78. http://dx.do.org/10.1016/j.jfca.2016.04.005

3 E. Damastuti, W.Y.N. Syahfitri, M. Santoso et al., Atom Indonesia 1 (2012) 29. http://doi.org/10.17146/aij.2012.138

4 I.O. Akinyele, O.S. Shokunbi, Food Chem. 173 (2015) 702. http://dx.doi.org/ 10.1016/ j.foodchem.2014.10.098

5 C. Thiry, A. Ruttens, L. De Temmerman et al., Food Chem. 130 (2012) 767. doi: 10.1016/j.foodchem.2011.07.102

6 N. Neufingerl, R. Djuwita, A. Otten-Hofman et al., J. Food Compos. Anal. 50 (2016) 36. http://dx.doi.org/10.1016/j.jfca.2016.05.006

7 A.M. Shraim, Arabian Journal of Chemistry 10 (2017) S3434. http://dx.doi.org/10.1016/ j.arabjc.2014.02.004
8 E. Pinto, A. Almeida, I.M.P.L.V.O. Ferreira, J. Food Compos. Anal. 48 (2016) 81. http://dx.doi.org/10.1016/j.jfca.2016.02.008

9 R.M. Barbosa, E.S. de Paula, A.C. Paulelli, et al., J. Food Compos. Anal. 45 (2016) 95. http://dx.doi.org/10.1016/j.jfca.2015.09.010

10 S. Kongsri, W. Srinuttrakul, P. Sola et al., Energy Procedia 89 (2016) 361. DOI: 10.1016/j.egypro.2016.05.047

11 J.H. Moon, M. Ebihara, B.F. Ni et al., J. Radioanal. Nucl. Chem. 291 (2012) 217. DOI: 10.1007/s 10967.011.1245.1

12 M. Wiyono, D. Iskandar, Wahyudi et al., Determination of Elements Contents In Rice Samples From Java Island with Neutron Activation Analysis, Proceedings of National Conference on Neutron Activation Analysis (2011) 163. (in Indonesian)

13 Anonymous, West Java in Figures 2015, BPS-Statistics Indonesia West Java (2015). (in Indonesian)

14 I. Ishaq, Science Plant Food. 6 (2011) 217. (in Indonesian)

15 W.Y.N. Syahfitri, E. Damastuti and S. Kurniawati, Heavy Metal $\mathrm{Cr}$, Co, $\mathrm{Zn}$, And $\mathrm{Hg}$ Concentration In Rice And Soybean From Bandung, Proceedings of National Conference on Neutron Activation Analysis (2011) 213. (in Indonesian)

16 S. Laoharojanaphand, A. Busamongkol, V. Permnamtip et al., J. Radioanal Nucl. Chem. 294 (2012) 323.

DOI: $10.1007 / \mathrm{s} 10967.012 .1884-\mathrm{x}$

17 J.A. Adeyemi, C.O. Adedire, A.C. Paulelli et al., J. Food Compos. Anal. 45 (2016) 34. http://dx.doi.org/10.1016.j.jfca.2015.09.015

18 G. Biego, M. Joyeux, P. Hartmann et al., Sci. Total Environ. 217 (1998) 27.

19 J.M.R. Antoine, L.A. Hoo Fung, C.N. Grant et al., J. Food Compos. Anal. 26 (2012) 111. DOI: $10.1016 /$ j.jfca.2012.01.003

20 A. Gustavo Gonzalez and M. Herrador, TrAC Trends Anal. Chem. 26 (2007) 227. DOI: 10.1016/j.trac.2007.01.009

21 W. Srinuttrakul and A. Busamongkol, Energy Procedia 56 (2014) 85.

DOI: 10.1016. egypro.2014.07.1358

22 P. Ekholm, H. Reinivuo, P. Mattila et al., J. Food Compos. Anal. 20 (2007) 47.

DOI: 10.1016/j.jfca.2007.02.007 
23 A. Gebrekidan, Y. Weldegebriel, A. Hadera et al., Ecotoxicol. Environ. Saf. 95 (2013) 171. http://dx.doi.org/10.1016/j.ecoenv.2013.05.035

24 K. Bashir, Y. Ishimaru and N.K. Nishizawa, Rice. 3 (2010) 122.

DOI: $10.1007 / \mathrm{s} 12284-010-9042-\mathrm{y}$

25 L.Nazemi, S. Nazmara, M.R. Eshraghyan et al., Iranian Journal and Environmental Health Science and Engineering 9 (2012) 1. http://www.ijehse.com/content/9/1/11

26 R. Prasad, Y.S. Shivay and D. Kumar, Agric. Res. 2 (2013) 111.

DOI: $10.1007 / \mathrm{s} 40003-013.0064 .8$

27 R. Kukuh and H. Djodjosubroto, Indonesian Journal of Nuclear Science and Technology III (2002) 35. (in Indonesian)

28 Liyanan, E. Septianingrum and B. Kusbiantoro, J. Sungkai 3 (2015) 65. (in Indonesian) 